EXPERIMENTAL STUDY

\title{
Effects of leptin on secretion of LH and FSH from primary cultured female rat pituitary cells
}

Koji Ogura, Minoru Irahara, Machiko Kiyokawa, Michiko Tezuka, Toshiya Matsuzaki, Toshiyuki Yasui, Masaharu Kamada and Toshihiro Aono

Department of Obstetrics and Gynecology, University of Tokushima School of Medicine, 3-18-15, Kuramoto-cho, Tokushima City, Tokushima 770-8503, Japan

(Correspondence should be addressed to K Ogura, Department of Obstetrics and Gynecology, University of Tokushima School of Medicine, 3-18-15, Kuramoto-cho, Tokushima City, Tokushima 770-8503, Japan)

\begin{abstract}
Background: Leptin, which is the product of the obese gene, is believed to play important roles in pubertal development and reproductive function in females. In a study using adult male rats, it was found that leptin stimulated secretion of gonadotropin from the pituitary in a dose-related manner. However, there has been no such study in female rats.

Objective: To investigate the effects of leptin on the production of LH and FSH from the pituitary in female rats, using primary cultured pituitary cells.

Methods: In this study, we determined body weight, serum leptin concentration and serum estradiol $\left(\mathrm{E}_{2}\right)$ concentration in female Wistar rats at 3, 5, 6, 7, 9 and 11 weeks of age, and cultured pituitary cells from 6-week-old female Wistar rats with leptin $\left(0-10^{-7} \mathrm{~mol} / \mathrm{l}\right)$ and $\mathrm{GnRH}\left(0\right.$ or $\left.10^{-8} \mathrm{~mol} / \mathrm{l}\right)$. Then basal and GnRH-stimulated extra- and intracellular LH and FSH were assayed by RIA.

Results: Serum leptin concentration increased with increases in body weight and $\mathrm{E}_{2}$ concentration. The pubertal serum leptin concentration was about $10^{-10} \mathrm{~mol} / \mathrm{l}$. At a lower or moderate concentration, leptin produced dose-related increases in both basal and GnRH-stimulated extraand intracellular LH and FSH in pituitary cells. At a concentration of $10^{-10} \mathrm{~mol} / \mathrm{l}$, leptin significantly $(P<0.05)$ stimulated both basal and GnRH-stimulated extra- and intracellular LH and FSH. However, at greater concentrations, these effects diminished.

Conclusions: These results indicated that leptin induced pituitary cells to produce and secrete both LH and FSH, with or without GnRH. The concentration of leptin that induced the greatest production of gonadotropins by pituitary cells was $10^{-10} \mathrm{~mol} / \mathrm{l}$, which was the same as the physiological pubertal concentration. Leptin may be involved in the onset of puberty. It is also conceivable that leptin may be a cause of ovulatory failure, not only in weight loss but also in weight gain.
\end{abstract}

European Journal of Endocrinology 144 653-658

\section{Introduction}

Leptin is a product of the obese gene (1). It is well known that leptin is secreted from adipose tissues and that it has an important role in the control of energy homeostasis $(2-5)$. Leptin receptors can be found throughout the body (6), including the hypothalamo -pituitary axis $(7,8)$, which is the center of reproductive function. Leptin has been reported to play important roles in reproductive function as well as in energy homeostasis.

In $o b / o b$ mice, chronic leptin treatment restored puberty and fertility $(9,10)$. In normal prepubertal girls, the serum leptin concentration increases earlier than that of other reproductive hormones related to puberty (11-13). In normal prepubertal female mice, the reproductive tract showed earlier maturation with leptin injection (14-17). In normal adult female rats, treatment with anti-leptin serum caused a decrease in luteinizing hormone (LH) pulsatility (18). In contrast, hyperleptinemia originating from extreme obesity has been reported to interfere with pituitary function (19). These reports indicate that leptin has an important role in reproduction through the hypothalamo-pituitary axis.

In a study using adult male rats, it was found that leptin induced secretion of LH and follicle-stimulating hormone (FSH) from the pituitary in a dose-dependent manner (20). However, there has been no such study in female rats. In this study, we therefore investigated the effects of leptin on the production of LH and FSH from the pituitary in female rats, using primary cultured pituitary cells. 


\section{Materials and methods}

\section{Animals}

Female Wistar rats were used in this study. The body weight of each rat was measured, and blood samples were taken from each rat for assays of serum estradiol $\left(E_{2}\right)$ and leptin concentrations at 3, 5, 6, 7, 9 and 11 weeks of age.

\section{Primary cell culture of the rat anterior pituitary}

Six-week-old female rats weighing 130-145 g were decapitated, and their pituitaries were excised. The pituitaries were cut into small pieces and washed in Dulbecco's modified Eagle's medium (DMEM; Nissui Co., Tokyo, Japan).

The cells were dissociated by treatment with $0.4 \%$ collagenase plus DNase at $37^{\circ} \mathrm{C}$ for $2 \mathrm{~h}$ and then incubated with pancreatin at $37^{\circ} \mathrm{C}$ for $7 \mathrm{~min}$, according to the method previously reported (21). The cells were seeded at $10^{6}$ cells $/ \mathrm{ml}$ in 24-well culture dishes (Falcon Plastics, Los Angels, CA, USA) and cultured for $48 \mathrm{~h}$ in DMEM containing 10\% fetal calf serum (FCS) at $37{ }^{\circ} \mathrm{C}$ under $5 \% \mathrm{CO}_{2}-95 \% \mathrm{O}_{2}$-humidified air. The FCS was treated with dextran-coated charcoal to remove endogenous steroids before use. After culture for $48 \mathrm{~h}$, the cells were washed three times with serumfree DMEM containing $0.1 \%$ bovine serum albumin and then incubated for $20 \mathrm{~h}$ in serum-free DMEM medium with leptin $\left(0-10^{-7} \mathrm{~mol} / \mathrm{l}\right)$.

For determination of basal extracellular gonadotropin concentrations, the supernatants were collected and assayed by RIA. The cells were then washed three times with serum-free DMEM and incubated in the DMEM medium with the same concentration of leptin as that stated above and with or without $10 \mathrm{nmol} / \mathrm{l}$ gonadotropin-releasing hormone (GnRH) (Sigma, St Louis, MO, USA). The cultures were then incubated for $4 \mathrm{~h}$ at $37^{\circ} \mathrm{C}$. The supernatants were aspirated and assayed by RIA for GnRH-stimulated extracellular LH and FSH release.

The cells were then washed with serum-free DMEM. One milliliter of Tris-HCl was added, the cells were removed from the dishes with a rubber remover, and the samples were sonicated $(20 \mathrm{kHz}, 160 \mathrm{~W})$ at $30 \mathrm{~s}$ intervals for $5 \mathrm{~min}$. They were then centrifuged at $10000 \mathrm{~g}$ for $10 \mathrm{~min}$ at $4{ }^{\circ} \mathrm{C}$, and the supernatants aspirated and assayed by RIA for intracellular LH and FSH content.

\section{Measurement of hormones}

Leptin was measured using a Rat Leptin RIA kit (LINCO Research Inc., St Charles, MO, USA). The intra- and interassay variances were $2.4 \%$ and $4.8 \%$ respectively. $\mathrm{E}_{2}$ was assayed using an Estradiol Kit (Diagnostic Products Corporation, Los Angeles, CA, USA). The intra- and interassay variances were $7.0 \%$ and $8.1 \%$ respectively. $\mathrm{LH}$ and $\mathrm{FSH}$ were measured by doubleantibody RIA with NHPP kits.

\section{Statistical analysis}

All data were calculated using the ANOVA program, and the significance of differences was examined by Student's $t$-test. Changes in body weight, serum leptin concentration and serum $\mathrm{E}_{2}$ concentration are expressed as means \pm s.E.M. Concentrations of LH and FSH are expressed as the means \pm s.E.M., with percentage of the control value.

\section{Results}

\section{Changes in body weight, serum leptin concentration and serum $E_{2}$ concentration}

Changes in body weight, serum leptin concentration and serum $\mathrm{E}_{2}$ concentration are shown in Fig. 1. The mean body weight increased from 3 to 11 weeks of age (Fig. 1A). Serum leptin concentrations increased in parallel with age and body weight. The mean concentration of leptin in rats at 6 weeks of age $(1.41 \pm 0.15 \mathrm{ng} / \mathrm{ml})$ was significantly $(P<0.05)$ greater than that in rats at 3 weeks of age $(0.91 \pm$ $0.14 \mathrm{ng} / \mathrm{ml})$ and lower than that in rats at 11 weeks of age $(2.32 \pm 0.23 \mathrm{ng} / \mathrm{ml}$; Fig. 1B). The pubertal serum leptin concentration was approximately $10^{-10} \mathrm{~mol} / \mathrm{l}$. Serum $\mathrm{E}_{2}$ concentrations also increased in parallel with age, body weight and serum leptin. The mean serum $\mathrm{E}_{2}$ concentration in rats at 6 weeks of age (17.8 \pm $1.4 \mathrm{pg} / \mathrm{ml})$ was significantly $(P<0.05)$ higher than that in rats at 3 weeks of age $(2.7 \pm 1.4 \mathrm{pg} / \mathrm{ml})$ and lower than that in rats at 11 weeks of age $(45.7 \pm$ $6.8 \mathrm{pg} / \mathrm{ml}$; Fig. 1C).

\section{Effects of leptin on basal extra- and intracellular LH and FSH from cultured pituitary cells}

Figure 2 shows the effects of leptin on basal concentrations of extra- and intracellular LH from cultured pituitary cells. Basal extracellular LH concentration increased with increases in leptin concentration up to $10^{-10} \mathrm{~mol} / \mathrm{l}(126 \%, P<0.05$ compared with control). However, at greater concentrations, these effects diminished (Fig. 2A). Basal intracellular LH content also increased with increases in leptin concentration up to $10^{-10} \mathrm{~mol} / \mathrm{l}(136 \%, \quad P<0.05$ compared with control; Fig. 2B), but these effects also diminished with greater concentrations.

Similarly, both basal extracellular and basal intracellular FSH concentrations also increased with increases in leptin concentration up to $10^{-10} \mathrm{~mol} / \mathrm{l}$ (106 and $160 \%$, respectively; $P<0.05$ compared with control). However, at greater concentrations, these effects also diminished (Fig. 3). 
(A)

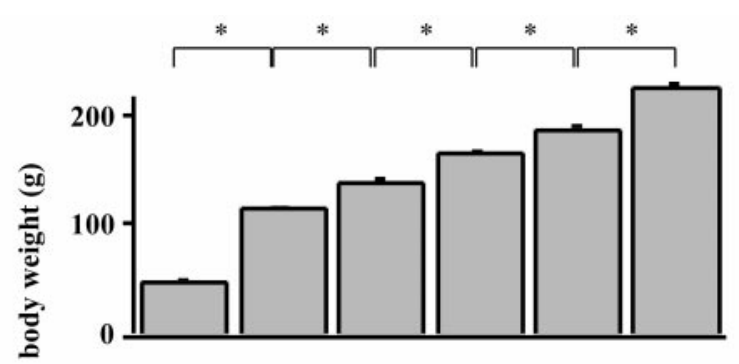

(B)

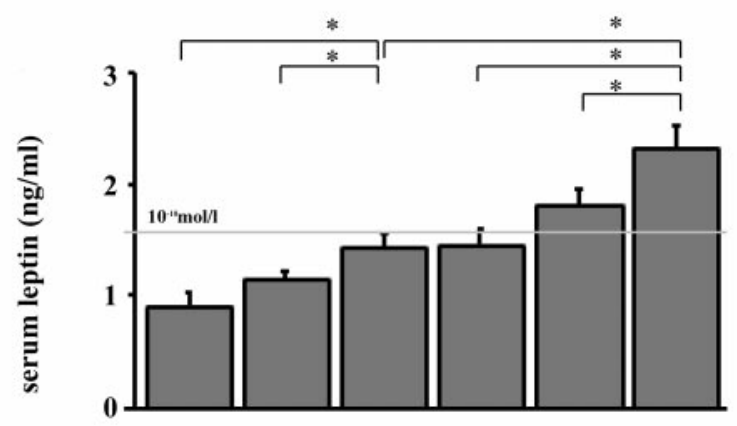

(C)

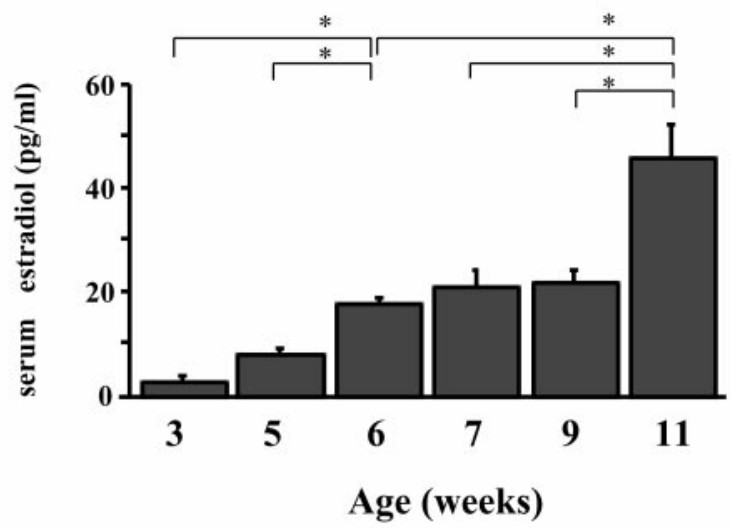

Figure 1 Changes in body weight, serum leptin concentration and serum estradiol $\left(E_{2}\right)$ in relation to age in female Wistar rats. (A) Changes in body weight $(n=8)$. Body weight steadily increased from 3 to 11 weeks of age. (B) Changes in serum leptin concentrations $(n=8)$. Serum leptin concentrations increased in parallel with age and body weight and increased significantly $(P<$ $0.05)$ in rats from 3 weeks of age $(0.91 \pm 0.14 \mathrm{ng} / \mathrm{ml})$ to 6 weeks of age $(1.41 \pm 0.15 \mathrm{ng} / \mathrm{ml})$, and in rats from 6 weeks of age to 11 weeks of age $(2.32 \pm 0.23 \mathrm{ng} / \mathrm{ml})$. The pubertal serum leptin concentration was approximately $10^{-10} \mathrm{~mol} / \mathrm{l}$. (C) Changes in serum $\mathrm{E}_{2}(n=8)$. Serum $\mathrm{E}_{2}$ concentrations increased in parallel with age, body weight and serum leptin concentration, and increased significantly $(P<0.05)$ in rats from 3 weeks of age $(2.7 \pm 1.4 \mathrm{pg} / \mathrm{ml})$ to 6 weeks of age $(17.8 \pm 1.4 \mathrm{pg} / \mathrm{ml})$, and in rats from 6 weeks of age to 11 weeks of age $(45.7 \pm 6.8 \mathrm{pg} / \mathrm{ml})$. Each bar and vertical line represents the mean \pm S.E.M. ${ }^{\star} P<0.05$.

\section{Effects of leptin on GnRH-stimulated extra- and intracellular $L H$ and FSH from pituitary cells}

Likewise, both GnRH-stimulated extra- and intracellular LH concentrations increased with increases in leptin
(A)

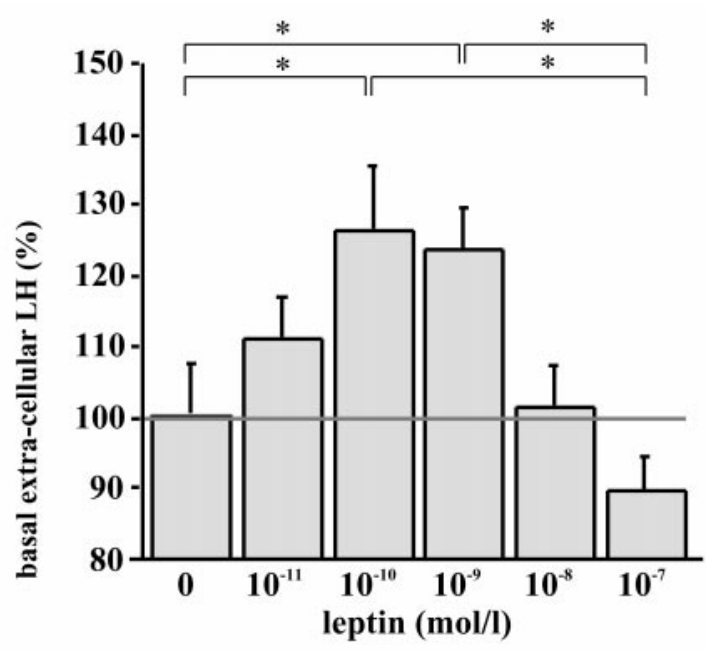

(B)

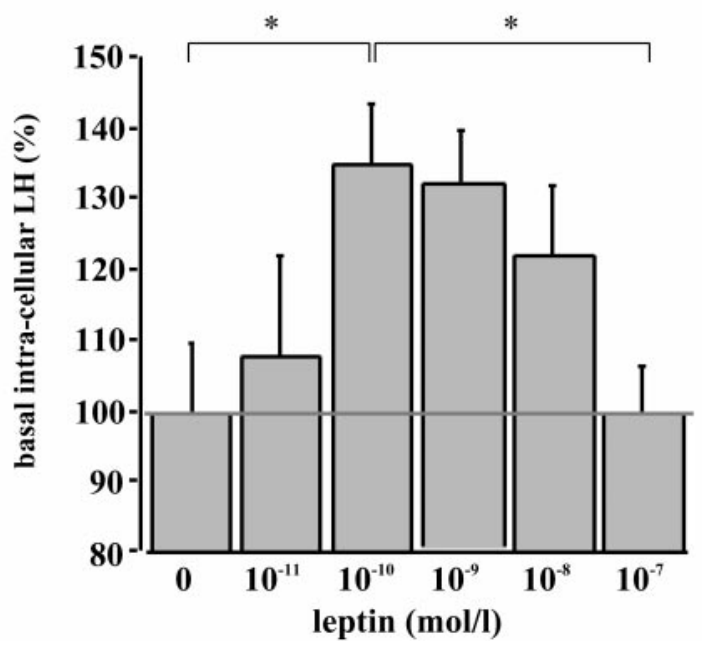

Figure 2 Effects of leptin on basal LH secretion and production. (A) Effect of leptin on basal extracellular LH $(n=12)$. (B) Effect of leptin on basal intracellular $\mathrm{LH}(n=5)$. Both basal extracellular and basal intracellular LH concentrations increased with increases in leptin concentration up to $10^{-10} \mathrm{~mol} / \mathrm{l}$ (126 and $136 \%$ respectively; $P<0.05$ compared with control). However, these effects diminished at higher concentrations. Each bar and vertical line represents the mean \pm S.E.M. with percentage of the control value. Control values of basal extra- and basal intracellular LH were $2.84 \pm 0.23$ and $21.19 \pm 1.99 \mathrm{ng} / \mathrm{ml}$ respectively. ${ }^{\star} P<0.05$.

concentration up to $10^{-10} \mathrm{~mol} / \mathrm{l}$ (150 and $133 \%$, respectively; $P<0.05$ compared with control). However, at greater concentration, these effects also diminished (Fig. 4).

Finally, both GnRH-stimulated extra- and intracellular FSH concentrations also increased with increases in leptin concentration up to $10^{-10} \mathrm{~mol} / \mathrm{l}$ (107 and $113 \%$, respectively; $P<0.05$ compared with control), but these effects also diminished at greater concentrations (Fig. 5). 
(A)

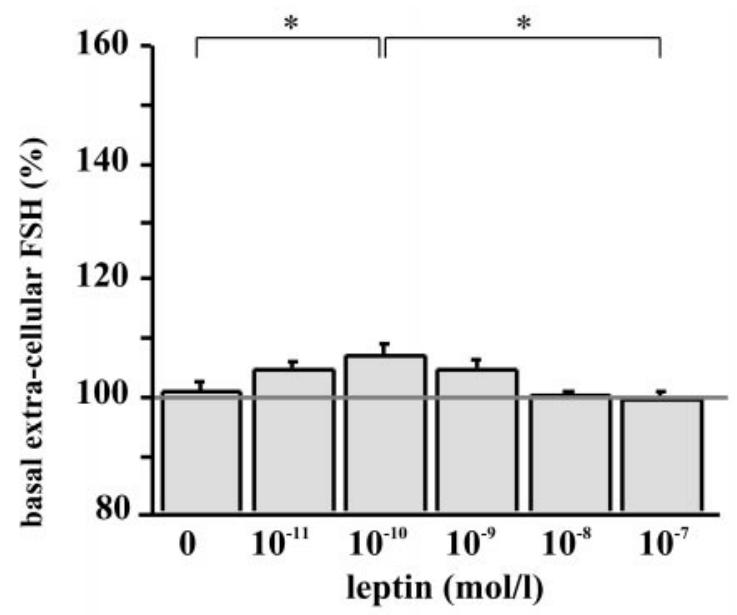

(B)

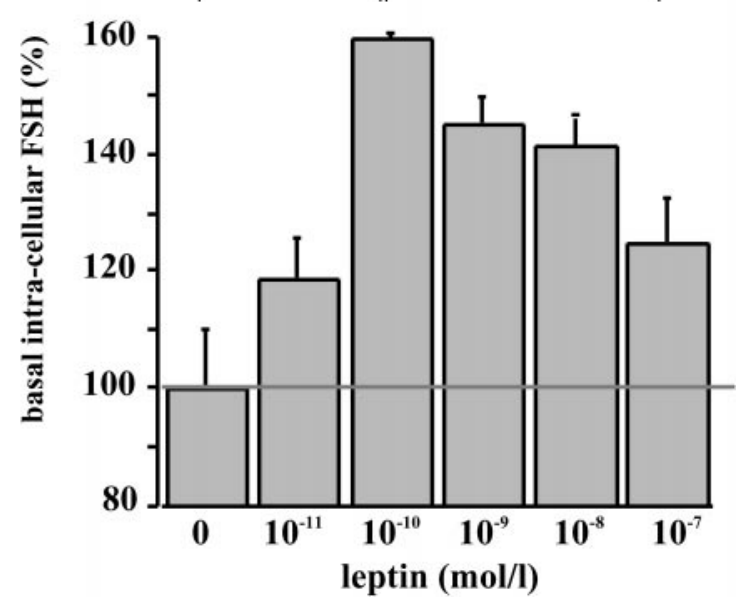

Figure 3 Effects of leptin on basal FSH secretion and production. (A) Effect of leptin on basal extracellular FSH $(n=12)$. (B) Effect of leptin on basal intracellular FSH $(n=5)$. Both basal extra- and intracellular FSH concentrations increased with increases in leptin concentration up to $10^{-10} \mathrm{~mol} / \mathrm{l}$ (106 and $160 \%$ respectively;

$P<0.05$ compared with control), but these effects also diminished at greater concentrations. Each bar and vertical line represents the mean \pm S.E.M. with percentage of the control value. Control values of basal extra- and intracellular FSH were $2.87 \pm 0.05$ and $4.77 \pm 0.47 \mathrm{ng} / \mathrm{ml}$ respectively. ${ }^{*} P<0.05$.

\section{Discussion}

Our findings demonstrate that leptin stimulates LH and FSH secretion from the cultured female rat pituitary, but that the effects are dose-related. Leptin stimulated both extra- and intracellular gonadotropins from pituitary cells with or without GnRH in the pubertal (6-7 weeks of age) concentration range, but did not stimulate at greater concentrations.

It is well known that the state of nutrition is an important factor in the reproductive function and the onset of puberty (22-28). Particularly in girls, body weight can be a better predictor of the pubertal
(A)

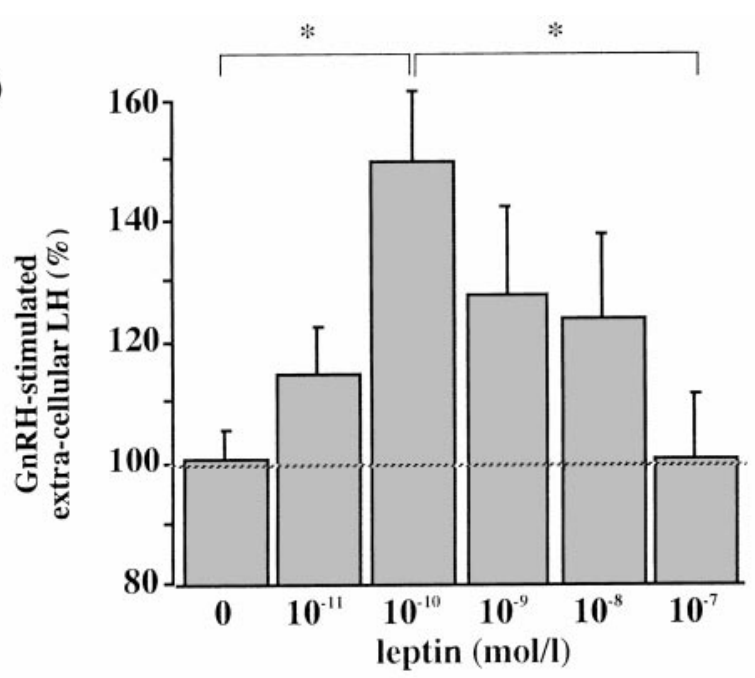

(B)

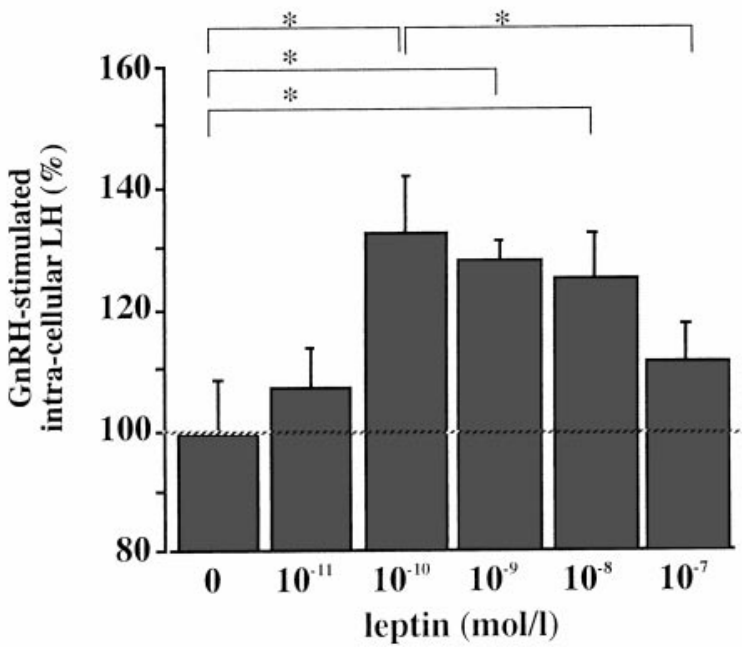

Figure 4 Effects of leptin on GnRH-stimulated extra- and intracellular LH. (A) Effect of leptin on $\mathrm{GnRH}$-stimulated extracellular $\mathrm{LH}(n=7)$. (B) Effect of leptin on $\mathrm{GnRH}$-stimulated intracellular LH $(n=7)$. Both GnRH-stimulated extra- and intracellular $\mathrm{LH}$ concentrations increased with increases in leptin concentration up to $10^{-10} \mathrm{~mol} / \mathrm{l}$ (150 and $133 \%$ respectively; $P<0.05$ compared with control), but these effects also diminished at greater concentrations. Each bar and vertical line represents the mean \pm S.E.M. with percentage of the control value. Control values of $\mathrm{GnRH}$-stimulated extra- and intracellular $\mathrm{LH}$ were $9.63 \pm 0.81$ and $4.34 \pm 0.35 \mathrm{ng} / \mathrm{ml}$ respectively. ${ }^{*} P<0.05$.

development than age. It has been proposed that the attainment of a critical body weight and a signal related to energy stores may determine the onset of puberty. However, the details are still not clear.

Leptin is produced by adipocytes (1), and an increase in leptin concentration is believed to serve as a negative feedback signal to the brain, resulting in decreased food intake, increased energy expenditure and resistance to obesity (2-5). In addition, leptin also appears to play important roles in reproductive functions and in pubertal development. In $o b / o b$ mice, chronic leptin 
(A)

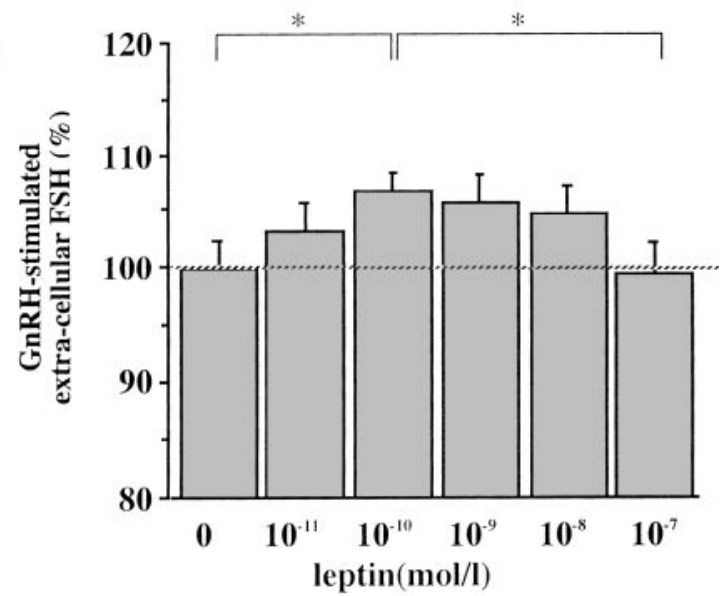

(B)

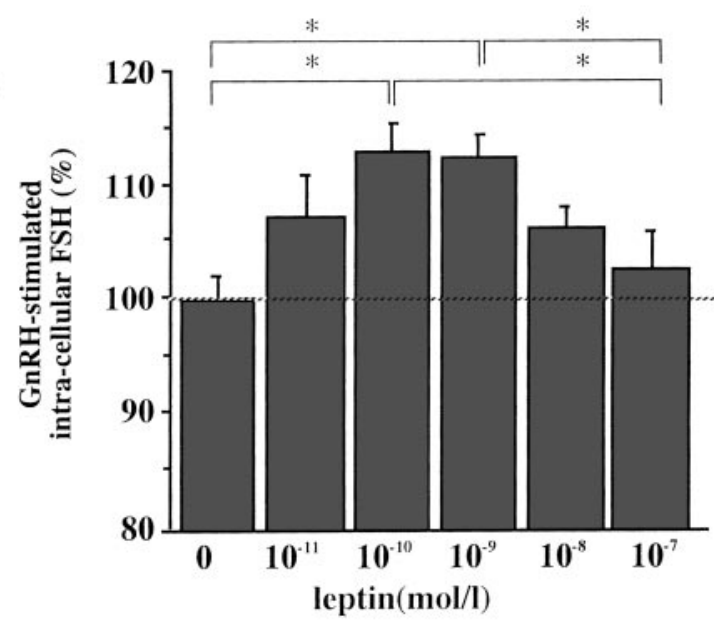

Figure 5 Effects of leptin on GnRH-stimulated extra- and intracellular FSH. (A) Effect of leptin on $\mathrm{GnRH}$-stimulated extracellular FSH $(n=7)$. (B) Effect of leptin on $\mathrm{GnRH}$-stimulated intracellular FSH $(n=7)$. Both GnRH-stimulated extra- and intracellular FSH concentrations increased with increases in leptin concentration up to $10^{-10} \mathrm{~mol} / \mathrm{l}$ (107 and $113 \%$ respectively; $P<0.05$ compared with control), but these effects were not found at greater concentrations. Each bar and vertical line represents the mean \pm S.E.M. with percentage of the control value. Control values of $\mathrm{GnRH}$-stimulated extra- and intracellular FSH were $7.48 \pm 0.19$ and $3.02 \pm 0.06 \mathrm{ng} / \mathrm{ml}$ respectively. ${ }^{*} P<0.05$.

treatment not only reduced food intake and body weight but also restored puberty and fertility $(9,10)$. In normal prepubertal girls, it was found that the serum leptin concentration increases before those of other reproductive hormones related to puberty (11-13). In the prepubertal period, weight gain in normal female mice was delayed by injection of leptin compared with that in control mice, but the mice injected with leptin showed earlier maturation of the reproductive tract (14-17). In normal adult female rats, anti-leptin serum decreased LH pulsatility (18), and in the adult male rat pituitary, leptin was found to produce a dose-related increase in gonadotropin release at lower or moderate concentrations (20). These findings suggest that leptin accelerates reproductive function.

In contrast, hyperleptinemia is associated with impaired basal and GnRH-stimulated gonadotropin secretion in humans during the peripubertal or early postpubertal period (19). In cultures of adult male rat pituitary, it was found that gonadotropin production was not induced by leptin at greater concentration $(20$, 29). It therefore seems that excessive leptin concentration reduces reproductive function.

Our results are consistent with both a positive and a negative correlation between leptin and gonadotropins. At lower or moderate leptin concentrations, leptin was effective for stimulating production and release of $\mathrm{LH}$ and FSH. At a pubertal concentration, leptin exerted maximal effect. However, at very high leptin concentrations, these effects diminished. It is likely that leptin is one of the factors critical to the onset of puberty, by which adipose tissue 'informs' the pituitary that the energy stores have attained an adequate level - a so-called critical weight. It is also likely that hyperleptinemia originating from extreme obesity may interfere with pituitary function.

Leptin receptors exist throughout the body (6), including the hypothalamus and the pituitary (7). Because of the density of leptin receptors on the hypothalamo-pituitary axis, leptin might affect the $\mathrm{GnRH}$ neuron mainly indirectly (8). In the hypothalamus, it may exert actions on the GnRH neuron both directly by modifying the frequency and magnitude of GnRH pulses (30), and more indirectly through intermediates such as nitric oxide (31), neuropeptide $\mathrm{Y}(32,33)$ and so on. In the pituitary, gonadotropin production might be induced by leptin directly or indirectly through modification of the sensitivity of the pituitary to GnRH. Further investigation of the effects of leptin on the hypothalamo-pituitary axis in reproduction in vitro is needed.

In summary, we have demonstrated that leptin has direct effects on pituitary cells. At the physiological pubertal concentration, leptin may stimulate the production and release of LH and FSH. Conversely, it may have inhibitory effects at very high concentrations. Our results indicate that leptin may play important roles in female reproductive function, the process of onset of puberty and ovulatory failure, not only in weight loss but also in weight gain.

\section{Acknowledgements}

We thank Dr K Shima and Dr T Murakami (Department of Laboratory Medicine, University of Tokushima School of Medicine) for supplying leptin.

\section{References}

1 Zhang Y, Proenca R, Maffei M, Barone M, Leopold L \& Friedman JM. Positional cloning of the mouse obese gene and its human homologue. Nature 1994372 425-432. 
2 Pelleymounter MA, Cullen MJ, Baker MB, Hecht R, Winters D, Boone T et al. Effects of the obese gene product on body weight regulation in ob/ob mice. Science 1995269 540-543.

3 Halaas JL, Gajiwala KS, Maffei M, Cohen SL, Chait BT, Rabinowitz D et al. Weight-reducing effects of the plasma protein encoded by the obese gene. Science 1995269 543-546.

4 Campfield LA, Smith FJ, Guisez Y, Devos R \& Burn P. Recombinant mouse ob protein: evidence for a peripheral signal linking adiposity and central neural networks. Science $1995 \mathbf{2 6 9}$ 546-549.

5 Arslanian S, Suprasongsin C, Kalhan SC, Drash AL, Brna R \& Janosky JE. Plasma leptin in children: relationship to puberty, gender, body composition, insulin sensitivity, and energy expenditure. Metabolism 199847 309-312.

6 Tartaglia LA, Dembski M, Weng X, Deng N, Culpepper J, Devos R et al. Identification and expression cloning of a leptin receptor, OB-R. Cell 199583 1263-1271.

7 Zamorano PL, Mahesh VB, De Sevilla LM, Chorich LP, Bhat GK \& Brann DW. Expression and localization of the leptin receptor in endocrine and neuroendocrine tissues of the rat. Neuroendocrinology $199765223-228$.

8 Håkansson M-L, Brown H, Ghilardi N, Skoda RC \& Meister B. Leptin receptor immunoreactivity in chemically defined target neurons of the hypothalamus. Journal of Neuroscience $1998 \mathbf{1 8}$ 559-572.

9 Barash IA, Cheung CC, Weigle DS, Ren H, Kabigting EB, Kuijper JL et al. Leptin is a metabolic signal to the reproductive system. Endocrinology 1996137 3144-3147.

10 Chehab FF, Lim ME \& Lu R. Correction of the sterility defect in homozygous obese female mice by treatment with the human recombinant leptin. Nature Genetics 199612 318-320.

11 Carlsson B, Ankarberg C, Rosberg S, Norjavaara E, AlbertssonWikland K \& Carlsson LMS. Serum leptin concentrations in relation to pubertal development. Archives of Disease in Childhood 199777 396-400.

12 Garcia-Mayor RV, Andrade MA, Rios M, Lage M, Dieguez C \& Casanueva FF. Serum leptin levels in normal children: relationship to age, gender, body mass index, pituitary-gonadal hormones, and pubertal stage. Journal of Clinical Endocrinology and Metabolism 199782 2849-2855.

13 Blum WF, Englaro P, Hanitsch S, Juul A, Hertel NT, Müller J et al. Plasma leptin levels in healthy children and adolescents: dependence on body mass index, body fat mass, gender, pubertal stage, and testosterone. Journal of Clinical Endocrinology and Metabolism 199782 2904-2910.

14 Ahima RS, Prabakaran D, Mantzoros C, Qu D, Lowell B, MaratosFlier E et al. Role of leptin in the neuroendocrine response to fasting. Nature 1996382 250-252.

15 Cheung CC, Thornton JE, Kuijper JL, Weigle DS, Clifton DK \& Steiner RA. Leptin is a metabolic gate for the onset of puberty in the female rat. Endocrinology 1997138 855-858.

16 Chehab FF, Mounzih K, Lu R \& Lim ME. Early onset of reproductive function in normal female mice treated with leptin. Science $199727588-90$.

17 Ahima RS, Dushay J, Flier SN, Prabakaran D \& Flier JS. Leptin accelerates the onset of puberty in normal female mice. Journal of Clinical Investigation 199799 391-395.

18 Carro E, Pinilla L, Seoane LM, Considine RV, Aguilar E, Casanueva FF et al. Influence of endogenous leptin tone on the estrous cycle and luteinizing hormone pulsatility in female rats. Neuroendocrinology 199766 375-377.
19 Bouvattier C, Lahlou N, Roger M \& Bougnères P. Hyperleptinaemia is associated with impaired gonadotrophin response to GnRH during late puberty in obese girls, not boys. European Journal of Endocrinology 1998138 653-658.

$20 \mathrm{Yu}$ WH, Kimura M, Walczewska A, Karanth S \& McCann SM. Role of leptin in hypothalamic-pituitary function. PNAS 1997 94 1023-1028.

21 Campen CA \& Vale W. Interaction between purified ovine inhibin and steroids on the release of LH and FSH from cultured rat pituitary cells. Endocrinology 1988123 1320-1328.

22 Rogers J \& Mitchell GW. The relation of obesity to menstrual disturbances. New England Journal of Medicine 1952247 53-55.

23 De Ridder CM, Thijssen JHH, Bruning PF, Van den Brande JL, Zonderland ML \& Erich WBM. Body fat mass, body fat distribution, and pubertal development: a longitudinal study of physical and hormonal sexual maturation of girls. Journal of Clinical Endocrinology and Metabolism 199275 442-446.

24 Kennedy GC \& Mitra J. Body weight and food intake as initiating factors for puberty in the rat. Journal of Physiology 1963166 $408-418$.

25 Frisch RE \& McArthur JW. Menstrual cycles: fatness as a determinant of minimum weight for height necessary for their maintenance or onset. Science 1974185 949-951.

26 Ronnekleiv OK, Ojeda SR \& McCann SM. Undernutrition, puberty and the development of estrogen positive feedback in the female rat. Biology of Reproduction $197819414-424$.

27 Hartz AJ, Barboriak PN, Wong A, Katayama KP \& Rimm AA. The association of obesity with infertility and related menstrual abnormalities in women. International Journal of Obesity 19793 57-73.

28 Frisch RE. Pubertal adipose tissue: is it necessary for normal sexual maturation?. Evidence from the rat and human female. Federation Proceedings 198039 2395-2400.

29 Tena-Sempere M, Pinilla L, González LC, Navarro J, Diéguez C, Casanueva FF et al. In vitro pituitary and testicular effects of the leptin-related synthetic peptide leptin (116-130) amide involve actions both similar to and distinct from those of the native leptin molecule in the adult rat. European Journal of Endocrinology 2000 142 406-410.

30 Magni P, Vettor R, Pagano C, Calcagno A, Beretta E, Messei E et al. Expression of a leptin receptor in immortalized gonadotropinreleasing hormone-secreting neurons. Endocrinology 1999140 1581-1585.

31 Yu WH, Walczewska A, Karanth S \& McCann SM. Nitric oxide mediates leptin-induced luteinizing hormone-releasing hormone (LHRH) and LHRH and leptin-induced LH release from the pituitary gland. Endocrinology 1997138 5055-5058.

32 Stephens TW, Basinski M, Bristow PK, Bue-Valleskey JM, Burgett SG, Craft L et al. The role of neuropeptide Y in the antiobesity action of the obese gene product. Nature 1995377 $530-532$.

33 Schwartz MW, Seeley RJ, Campfield LA, Burn P \& Baskin DG. Identification of targets of leptin action in rat hypothalamus. Journal of Clinical Investigation 199698 1101-1106.

Received 18 October 2000

Accepted 2 February 2001 